DOI: 10.12957/demetra.2017.26407

\title{
Pedagogical school gardens as a Food and Nutrition Education strategy: perception of parents and educators of their impact on children's diets
}

\author{
Hortas escolares pedagógicas como estratégia de Educação Alimentar e Nutricional: \\ percepção de pais e educadores sobre os impactos na alimentação das crianças
}

\author{
Mariana Tarricone Garcia' \\ Denise Eugenia Pereira Coelho² \\ Cláudia Maria Bógus² \\ 1 Instituto Brasileiro de Defesa do Consumidor \\ (Idec). São Paulo-SP, Brasil. \\ ${ }^{2}$ Universidade de São Paulo, Faculdade de Saúde \\ Pública, Departamento de Prática de Saúde \\ Pública. São Paulo-SP, Brasil \\ Funding: This research project received grants \\ from FAPESP (Protocol no. 2011/23.187-3) \\ Correspondence / Correspondência \\ Mariana Tarricone Garcia \\ Instituto Brasileiro de Defesa do Consumidor \\ (Idec). Rua Desembargador Guimarães, 21. São \\ Paulo, SP 05002-050. São Paulo-SP, Brasil \\ E-mail:marianatarricone@gmail.com
}

\begin{abstract}
Introduction: Schools have been recognized as a favorable setting for food and nutrition education and school-based garden interventions have shown positive results. Objective: The objective of this study was to describe the dietary-related impact of children's experience with growing foods in school gardens, according to the perception of parents and educators. Methods: In-depth interviews were conducted with principals, teachers and employees, and semistructured in-home interviews with parents of school children from three municipal schools in Greater São Paulo. A total of 27 individuals were interviewed, comprising 19 parents and eight educators. Results and discussion: The school garden promoted reflection on the act of eating and on foods through the knowledge gained from direct contact with growing food crops. The experience had an impact on both the children and the families involved with the activities. Contact with food production provided knowledge about food and strengthened connections with the food grown by sensitization to the act of eating. In practice, this resulted in concrete dietary-related changes, greater knowledge of foods and the food system, in addition to greater appreciation of the food produced as well as motivation to try new foods. Conclusion: School gardens are conceived as a food and nutrition education strategy based on involvement and direct contact with food.
\end{abstract}

Keywords: Gardening. Food and Nutrition Education. School Health. 


\section{Resumo}

Introdução: As escolas têm sido reconhecidas como um ambiente favorável para a educação alimentar e nutricional, e intervenções baseadas em hortas escolares têm mostrado resultados positivos. Objetivo: Descrever o impacto na alimentação associado à experiência de crianças na produção de alimentos em hortas escolares, de acordo com a percepção de pais e educadores. Métodos: Foram realizadas entrevistas em profundidade com diretores, professores e funcionários, e entrevistas domiciliares semiestruturadas com pais de alunos de três escolas de uma cidade da Grande São Paulo. Um total de 27 indivíduos foram entrevistados, sendo 19 pais e 8 educadores. Resultados e discussão: A horta escolar proporcionou a reflexão sobre o ato de comer e sobre os alimentos, através do conhecimento adquirido com o contato direto com o cultivo desses alimentos. A experiência teve um impacto sobre as crianças e famílias envolvidas com tais atividades. O contato promoveu compreensão sobre a comida e fortaleceu esta conexão, bem como maior sensibilização para o ato de comer. Na prática, isso resultou em mudanças concretas na alimentação, maior conhecimento sobre os alimentos e o sistema alimentar, além de maior valorização dos alimentos produzidos e estímulo para experimentar novos. Conclusão: A horta escolar é, assim, uma estratégia de educação alimentar e nutricional com base no envolvimento e relação direta com alimentos.

Palavras-chave: Jardinagem. Educação Alimentar e Nutricional. Saúde Escolar.

\section{Introduction}

The literature in the field of public health reports numerous health benefits from greater consumption of fruit and vegetables (F\&V) and lower intake of ultra-processed foods. ${ }^{1,2}$ National dietary data on Brazilian children under five years of age reveals low F\&V intake, high consumption of cookies, soft drinks, sweet products and salted snacks, in addition to a high prevalence of overweight, anemia and hypovitaminosis A. This scenario points to the need for actions that promote access to adequate and healthy food. ${ }^{3,4}$ Involvement in school-based gardens has shown positive food-related outcomes of participating children. ${ }^{5,6}$ The present study reports the perception of parents and educators on the children's experience in growing foods in school gardens.

Schools are recognized as a favorable setting for food and nutrition education (FNE).-9 Actions within schools can promote processes of change within the family and community environments 
and contribute toward improving academic performance through a healthier diet among students and greater parental involvement. ${ }^{10}$ The main strategies used in FNE actions within Brazilian schools have been based on traditional approaches such as talks, discussions and presentations. These activities, however, do not provide practical involvement and experience; thus, there is a need for methods that embrace the subjectivity of the educational process and related factors, given that dietary habits are socially and culturally determined. ${ }^{11}$

Interventions involving school-based gardens for FNE have shown positive dietary-related outcomes of participating children and in the processes determining eating habits. These benefits include the "learning by doing" experience, direct involvement, and the opportunity for children to learn outside the traditional classroom environment. ${ }^{5}$ Having a garden in the school premises increases students' contact with $\mathrm{F} \& \mathrm{~V}$, exposing them to new varieties of foods as they grow, prepare and consume the produce. ${ }^{6}$ School gardens allow integration of various health-determining processes (eating habits, physical activity and social interaction) into a single activity. They can be used as an instrument for FNE and an important teaching resource for schools, ${ }^{12,13}$ involving cognition, subjectivity, emotion and integration of different fields of knowledge. ${ }^{14}$

School gardens are not new in Brazil, but there is a dearth of studies investigating the use of this type of strategy among school children. ${ }^{15}$ The majority of studies published to date report results of interventions involving school gardens as short-term programs. ${ }^{12,16,17}$ However, there is a scarcity of studies in the literature reporting experiences of school gardens that are integrated into the school curriculum.

The objective of the present study was to describe the dietary-related impact of an experience of growing foods in school gardens involving school children, according to the perception of parents and educators. In Brazil, public policies such as the National Program of School Food and the Health in Schools Program place emphasis on the importance of food-related educational processes within the school setting, including recommendations for the implementation of school gardens..$^{18}$ Therefore, the present study can contribute to the body of evidence by reporting findings on these actions.

\section{Methods}

\section{Background and setting}

This study was part of a larger research project whose objective was to elucidate the importance and impact of activities and projects in the field of urban agriculture on health promotion and quality of life. 
Since 2008, a number of experiences developing agroecological urban agriculture have become well-established in the city of Embu das Artes, located in the metropolitan region of São Paulo. Some of these activities, originated from a local project called the School Source Program (PFE), a collaborative initiative between the non-governmental Ecological Society Friends of Embu and local authorities, involved groups of children from public schools in the region, provided pedagogical support to educators, and developed gardens based on a School Gardens course. ${ }^{19}$ Three schools were selected for the present study; at the time of the study, they had active school gardens as part of the teaching curriculum that were long-term interventions.

The first school was a municipal pre-school for 3-5 year-olds. At the time of the study, all of the teachers, some employees, and students took part in the garden activities. Since 2013, these activities have been run on a weekly basis as part of the school curriculum, together with activities for the upkeep of the school as a whole (called "collaborative efforts"). "Special meals" were prepared and had the children's involvement, ranging from the process of harvesting produce from the garden for use in the recipes to laying the table in the school garden where the meals were served.

In another municipal pre-school, all of the teachers, the catering staff, and preschoolers took part in the gardening activities. The teachers incorporated the garden activities into their teaching schedules roughly on a weekly basis, with occasional help from the children to pre-prepare the school meals. In addition, "collaborative efforts" were undertaken by the school staff, parents and their children.

The third one was a primary school (up to year 5) for 6-11 year-olds. One teacher was directly in charge of the garden and the related classes. The teachers devised their teaching plans and, based on them, the gardening teacher structured the content and activities in the garden. These "garden classes" were taught once a week as part of the curriculum framework and all children took part in them.

Garden observation visits were made to the three municipal schools in order to collect information on the activities, actors, participants and work dynamics. A key informant, the person most involved in the garden, was selected in each school.

\section{Study Population}

Given that all of the teachers, principals and employees that were interviewed played the role of educator in the gardens, they shall hereafter be referred to as such in the context of this study. The teachers were responsible for teaching classes, the principals were managers of the schools and were in charge of everything involving the school and the staff, and the employees were technical professionals involved in administrative, gate-control, catering, cleaning and secretarial duties. 
The selection of the interviewees in the educator category intentionally included different profiles of involvement in the garden activities. The key informants indicated those educators for the interviews at each school. The key informants were also asked to provide a list of no more than 20 school children that were most involved in the gardens, resulting in an overall list of 39 parents/guardians of school children from the three schools.

The educators selected for interview and the parents/guardians of the school children in the list were invited to take part in the study by telephone or in person. All of the educators invited agreed to take part in the study. Of the 39 parents of the school children, six telephone numbers were incorrect, eight parents did not answer the phone and six were unavailable for the interview, hence a total of 19 interviews were conducted.

\section{Data collection procedures}

Interview scripts were devised based on the observation visits at the schools and on the materials received, such as activity reports, photographic records and media publications.

The interviews were performed by two nutritionists holding graduate degrees in Public Health and authors of this article. They both have experience in qualitative research and data collection and have knowledge of Food and Nutrition Security, Health Promotion and Education. The involvement of the researchers with the schools commenced with this research project. All interviews were conducted between the interviewee and the interviewer only. In some cases, the child was present at the interview with the parent/guardian.

Parents of the school children had semi-structured interviews entailing application of a sociodemographic questionnaire and another interview about gardening practices. In-depth interviews were carried out with educators.

Data collection was carried out between October and November 2013. Responses to the questionnaires administered to parents were keyed into the Epi InfoTM program (Centers for Disease Control and Prevention, Atlanta, USA). The database was subsequently exported to the SPSS statistical package (IBM, New York, USA) for data treatment and analysis.

\section{Data analysis}

The materials (sound recordings and notes) taken during the semi-structured and in-depth interviews with parents and educators, respectively, were input to a database for analysis using the NVivo10 software (QSR International Pty Ltd. Version 10, 2012). The transcribed material was analyzed by the same researchers who conducted the interviews while the third co-author 
oversaw the analysis process. Analysis of the evidence gathered was done by content-analysis. ${ }^{20}$ This involved breaking down the transcribed text into categories, revealing the core themes, and structuring them according to the themes relative to Health Promotion and Adequate and Healthy Food and Nutrition. For the purpose of this study, healthy diet was defined as a health determinant; diet was considered culturally and socially constructed, and the dimensions of social determinants, access, environment and food systems were focused. ${ }^{21-23}$ The analysis entailed three stages: pre-analysis - during which ideas were organized and systematized, with floating reading and formulation of hypotheses; material exploration - to classify the information; and lastly, treatment of data and interpretation - performed together with the researchers. A priori categories were not established ${ }^{20}$ because this categorization model may not have guaranteed the density and richness of the material. ${ }^{24}$

\section{Ethical aspects}

The research project was approved by the Research Ethics Committee of the School of Public Health of the University of São Paulo. All study participants were duly informed on the overall objective of the study and agreed to take part by signing a Free and Informed Consent Form.

\section{Results}

A total of 27 individuals were interviewed, comprising 19 parents of school children, four teachers, two employees and two school principals. Table 1 shows the sociodemographic profiles of the interviewees. The population of parents comprised individuals that were predominantly women (89\%), older than 30 years (79\%), with high-school education or higher education (73\%), currently employed (58\%), and who had moved to Embu (84\%) from other cities within São Paulo state (69\%). The group of educators also comprised predominantly women (87\%), older than 40 years $(79 \%)$, and with higher education $(75 \%)$ in teaching (100\%). Lastly, half of the educators had previously lived in a rural area, and one of these individuals still lived in the countryside at the time of the interview. 
Table 1. Sociodemographic characteristics of the population interviewed. Embu das Artes, SP, 2013.

\begin{tabular}{|c|c|c|}
\hline Interviewees & $\mathrm{N}$ & $\%$ \\
\hline \multicolumn{3}{|l|}{ Parents/Guardians $(n=19)$} \\
\hline \multicolumn{3}{|l|}{ Gender } \\
\hline Female & 17 & 89.5 \\
\hline Male & 2 & 10.5 \\
\hline \multicolumn{3}{|l|}{ Age Group } \\
\hline $20-29$ years & 4 & 21.1 \\
\hline $30-39$ years & 12 & 63.2 \\
\hline $40-50$ years & 3 & 15.8 \\
\hline \multicolumn{3}{|l|}{ Education } \\
\hline Finished primary school & 5 & 26.3 \\
\hline Finished high-school/technical school & 11 & 57.9 \\
\hline Finished higher education & 3 & 15.8 \\
\hline \multicolumn{3}{|l|}{ Employment status } \\
\hline Not working & 5 & 26.3 \\
\hline Working & 11 & 57.9 \\
\hline Unemployed & 3 & 15.8 \\
\hline Migrants & 16 & 84.2 \\
\hline São Paulo & 11 & 68.8 \\
\hline Bahia & 2 & 12.5 \\
\hline Pernambuco & 2 & 12.5 \\
\hline Minas Gerais & 1 & 6.2 \\
\hline
\end{tabular}


Continuation of Table 1

\begin{tabular}{lll}
\hline Interviewees & $\mathrm{N}$ & $\%$ \\
\hline
\end{tabular}

\section{Educators $(n=3)$}

Gender

Female

Male

Age Group

30-39 years

40-49 years

$50-59$ years

\section{Education}

Finished primary school

Finished technical school

Finished higher education

Home state

São Paulo

Bahia

Ceará

Minas Gerais

The parents in seven families of school children had a domestic garden (34\%). They were not asked whether the domestic gardens existed before their children became involved in the school garden. The varieties most grown were herbs and spices $(86 \%)$, plants for medicinal use $(86 \%)$, vegetables $(57 \%)$ and fruit $(57 \%)$. The majority of the harvest from domestic gardens was shared with neighbors and family. Out of the 19 parents, $18(95 \%)$ had previously visited the school garden and 14 (74\%) had taken part in or kept track of the school garden activities. The nature of the participation of the parents ranged from active participation in the garden (79\%), consumption of the foods harvested at the school garden $(64 \%)$, sharing the knowledge acquired by the student (43\%), contribution with supplies for the upkeep of the garden (29\%) and taking part in planning meetings $(21 \%)$. 
Based on the semi-structured interviews with parents and the in-depth interview with educators, three main thematic categories and nine sub-categories were identified. They are shown in Chart 1 and outlined below.

Chart 1. Categories and sub-categories identified from interviews with parents of school children and educators of the participating schools about the school garden.

\section{The "learning by doing" process}

1.1 Involvement of children in meal preparation

1.2 Experience of eating what you plant

1.3 Children's contact with earth and nature

\section{Impact on the children}

2.1 Changes in children's diet

2.2 Awareness of the food system

2.3 Knowledge of foods

\section{Impact on the family}

3.1 Family involvement in preparing foods grown in the school garden

3.2 Changes in family's diet

3.3 Relationship with home gardens

\section{The "learning by doing" process}

Table 2 shows some examples of discourse for the sub-categories of the process of involvement in the school garden. 


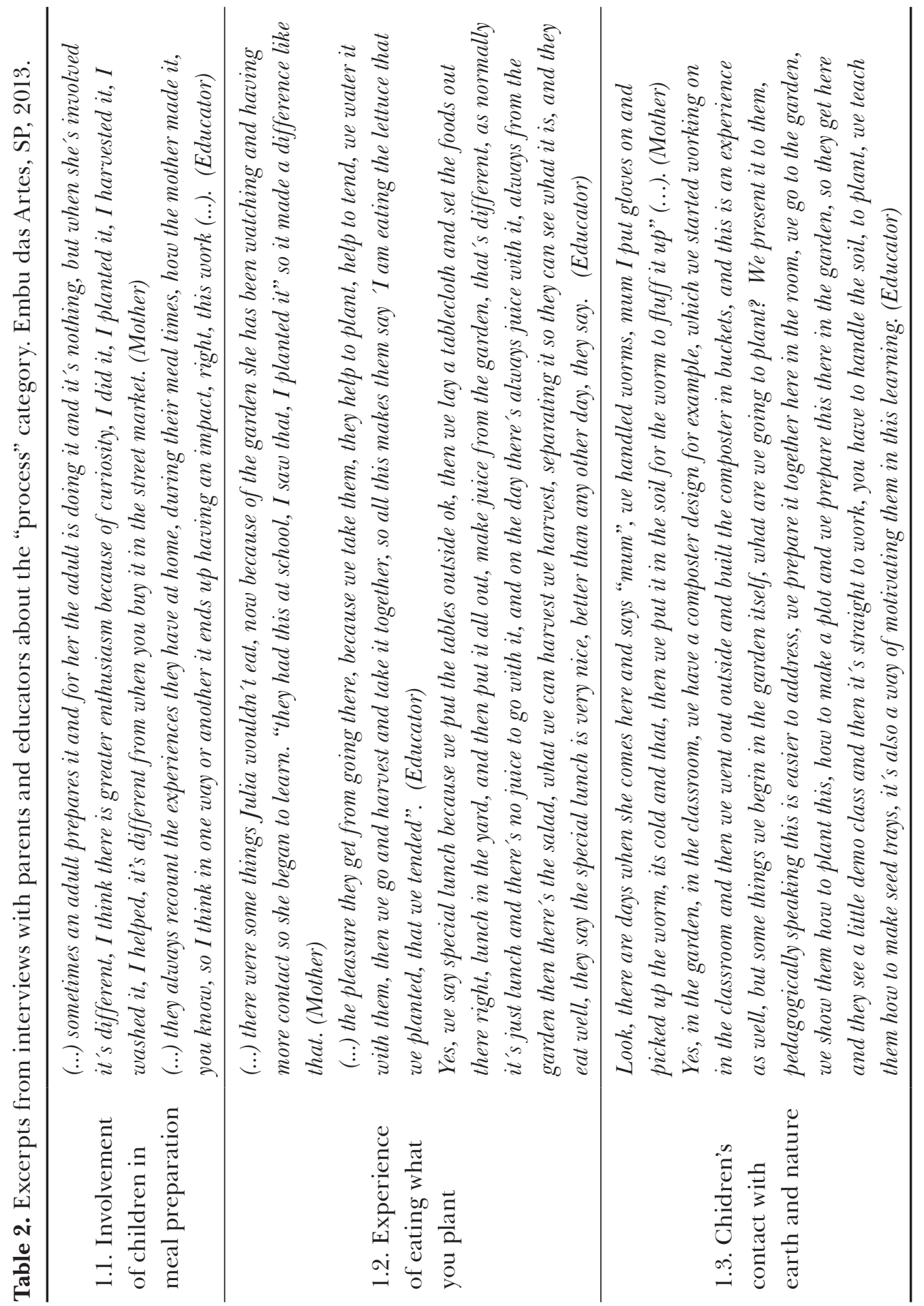




\subsection{Involvement of children in meal preparation}

The parents reported that the children showed greater interest in participating in meals at home; they asked their parents to prepare, at home, the foods they had eaten at school, thus taking part in decisions about the menu and preparation of the foods. The parents attributed the children's increased interest in playing an active role to the cultivation of food in the school garden, and, likewise, their interest in consuming the food which they helped prepare. The children told their parents about the foods they prepared and consumed at school, prompting some of the parents to prepare some of the school recipes with them at home, e.g., "garden juice".

\subsection{Experience of eating what you plant}

The children's experience in eating foods they had grown themselves was also associated with their enthusiasm and pride in their involvement in the process. The children recounted the times when they also helped prepare the foods, and this was associated with the pleasure of consuming them. The parents reported that acceptance of these foods at school was high, particularly when the child was involved in the preparation. Greater acceptance was also associated with the fact that children related food they at home with food they had previously grown in the school garden.

The educators reported that the fact the children had participated in the planting of the food encouraged them to get to know, try and eat what was planted, widening their choices and, thus, producing healthier and more meaningful food. They affirmed that the fact that children had participated in the whole process helped them form a connection with the food.

In one school, in addition to the involvement in the garden, an activity called "special meal" was ran in which children took part in the whole ritual of preparing and presenting the meal on the day, using foods harvested from the garden. According to the school's educators, this activity also promoted better acceptance of the vegetables.

\subsection{Children's contact with earth and nature}

The parents reported that the children liked to handle the soil along with the plants and worms, and emphasized the importance of "getting their hands dirty" and the joy in seeing their children enjoy the opportunity of having this contact and learning from tending the garden. The experience in the garden allowed children to observe the animals that were part of the ecosystem and discover the roles of each one of them. They also witnessed the different growth stages of the plants and told their parents about the changes. One of the schools put each child in charge of a vegetable crop, from sowing to harvest, which also sensitized the children to the act of nurturing. 
The educators also affirmed that direct contact with nature taught the children to care for it and it was more important than teaching such care in theory because it sparked greater interest in the children. Thus, all the learning to develop the garden involved practical activities with the children, and it was also associated with moments of discovery, as a means of motivating them.

\section{Impact on the children}

Table 3 shows examples of discourse for the sub-categories addressing the dietary-related impact of participating in the school garden. 


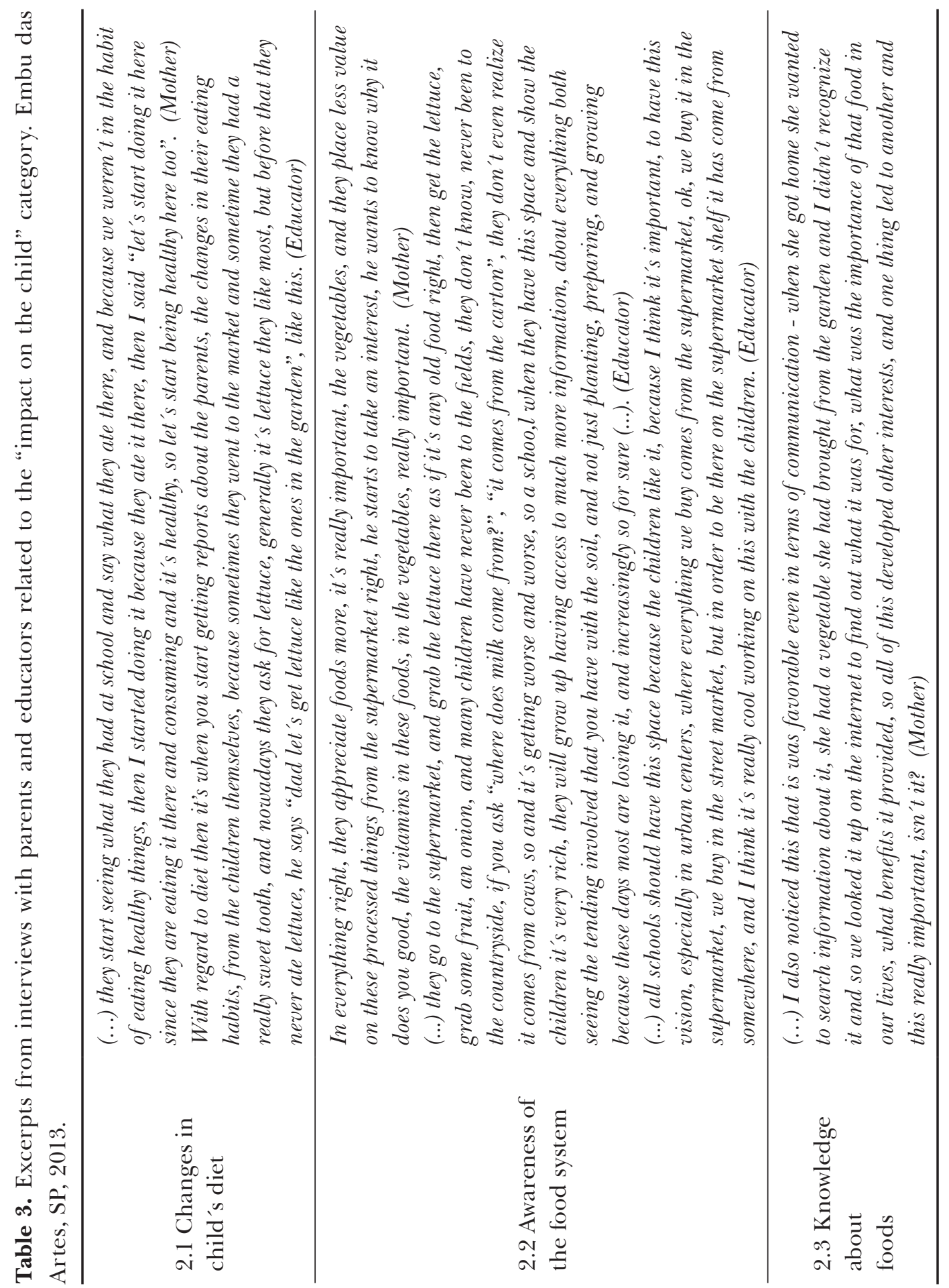




\subsection{Changes in children's diet}

The majority of the parents reported acceptance of vegetables as a result of taking part in the school garden. According to the parents, the fact their children had contact with nature and participated in the planting, tending, harvest and preparation of the foods sparked their interest and led to improved acceptance. The parents also reported that their children were enthusiastic about telling the family about their participation in the school garden and what was prepared and eaten. The school was perceived as a partner of parents in promoting adequate and healthy food for the children, helping the family to make similar changes at home.

The educators also mentioned that parents reported these dietary-related changes in their children. One educator stated that, after the garden experience started, the children asked their parents to purchase vegetables and they also ate less ultra-processed food. Another educator reported that, in the course of the year, the children showed greater acceptance of vegetables and legumes.

\subsection{Awareness of the food system}

The parents reported that through participation in the school garden, their children raised their awareness about the food system, thereby appreciating "natural" foods more. This appreciation was attributed to the knowledge and experience acquired in the garden about the life cycle and origin of the foods. There was also greater interest from the children in learning about the nutritional properties of the foods, including refusal of ultra-processed foods.

The educators also stated that participation in the gardens allowed the children to discover the origin of the foods. One of the educators made a specific mention of the importance of the garden for understanding, even on a basic level, how the food system works. The educator said that the practical activity was also a way of appreciating the work involved in planting a food crop, a concept that the children had not been aware of up until then.

\subsection{Knowledge of foods}

Participation in the planting and harvesting of the foods from the garden allowed the children to get to know new foods, broadening the children's repertoire of choice at meal times. This wider repertoire of foods recognized by the children was a type of knowledge reported by the parents gleaned from growing foods in the school garden. According to the parents, by participating in the school garden, the children also developed curiosity about the foods, and shared their knowledge with the family. The habit of reading food labels was also noted, along with greater interest in the nutritional value of food products. 


\section{Impact on the family}

Table 4 shows examples of discourse for the sub-categories addressing the dietary-related impact on the families as a result of the children's participation in the school garden. 


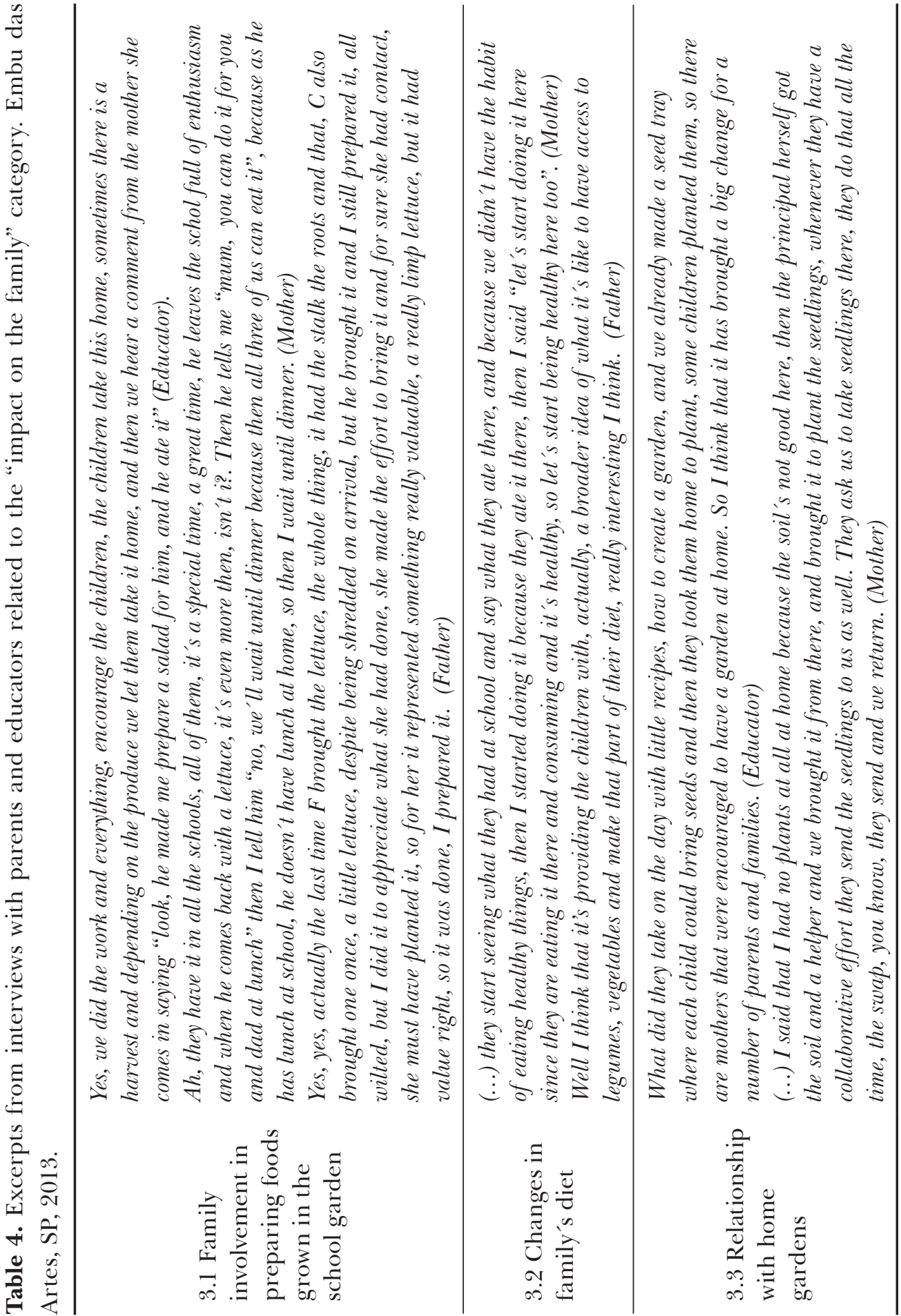




\subsection{Family involvement in preparing foods grown in the school garden}

Some of the educators affirmed that the parents reported that the children asked to prepare meals using the food brought from the school garden.

The experience of bringing home a food grown in the school garden was significant for parents and children, with the children recalling when they had eaten something similar at school. The parents described the children's joy at seeing the family eating a food they had grown, and one of the parents considered the food a gift for the family.

As regards activities run at the school, one of the educators reported that the students took foods grown in the school garden for preparation with the parents as a way of involving them in the garden activities, stimulating interest and greater involvement on the part of the parents.

This preparation of the food brought by the child was described as a way of appreciating the children's efforts in the garden. One of the teachers asked parents to write down the recipe that was prepared and send it into school to be displayed on the school garden notice board.

\subsection{Changes in the families' diet}

Involvement in the garden also had an impact by changing the diet of some families that, influenced by the child, also started consuming vegetables not eaten beforehand. The promotion of adequate and healthy food by the school often extended to the family's diet, where parents recognized the need to keep up this effort at home.

Many parents cited the key role of the school garden in providing food and nutrition education by increasing exposure to fruit and vegetables. Many parents voiced their difficulties in promoting adequate and healthy eating at home, emphasizing the positive collaboration of the school. The main goals mentioned included greater acceptance of vegetables, a "broader" awareness about food and greater appreciation of foods. The parents highlighted the importance of the activity for the future, since the children "learned" to eat "better" and consume more fruit and vegetables.

\subsection{Relationship with home gardens}

The learning gleaned from the school garden led to the creation of gardens at children's homes. One of educators reported that some school children brought in seedlings from home for the school garden. Another educator reported that children had taken home the seed tray produced at school to plant at home and this had contributed toward developing gardens at the homes of some families. 
According to reports by parents, many children had asked for gardens to be set up at home, which was viewed as challenging by some parents because of lack of space. Some parents had successfully set up domestic gardens with the active participation of their child, who asked if they could show their teacher what they were growing at home. The exchange of seedlings between parents with gardens and the school was also reported.

\section{Discussion}

The present study reports the perception of parents and educators of the children's experience growing food crops in school gardens. Although the population interviewed was predominantly comprised of economically active women, this study addressed a population with different types of contact with children and gardens. The educators took part in the activities together with the children and experienced the effects on the school and themselves. Parents, on the other hand, shared the effects of these activities on the children outside the school setting and within the family environment. Consequently, the analysis of the interviews produced shared categories and subcategories of analysis. It should be highlighted that school gardens alone are unable to have this much of an impact, where the teaching goal and inclusion of the school gardens as part of the teaching policy were fundamental in attaining the outcomes observed. The difficulties and challenges that can occur in developing school gardens should also be noted, such as organizational and institutional constraints; lack of commitment of administrators and educators; lack of involvement of the school children, their parents and the community; shortage of funding; inadequate physical space; lack of skills on the part of educators, among others.

The role of the garden was conceived as a Food and Nutrition Education strategy. According to Silva and Fonseca, ${ }^{14}$ school gardens in an urban setting facilitate the perception of the agricultureenvironment-dietary habits interface in the context of the field of Environmental and Health Education. Regarding greater involvement of children in meal preparation, a review study on cooking activities among school-aged children showed that these activities can positively impact foodrelated habits, such as greater willingness to try new foods, as well as greater preference for and higher consumption of F\&V, hence revealing that cooking can be a promising tool for promoting positive changes in children's preferences, attitudes and behaviors. ${ }^{25}$ Van der Horst et al. ${ }^{26}$ reported a statistically significant increase in vegetable intake when children were involved in preparing meals, explained by greater feelings of autonomy and pride because of the combination of choice and independence in preparing meals.

On the subjectivity of the experience of eating what you plant, an experience was conducted in Hawaii in which teachers and employees involved in a school garden reported that this process of growing and harvesting their own food gave children a sense of achievement. ${ }^{27}$ It should 
be pointed out that the act of eating is not a purely biological activity, but a social and cultural phenomenon. Thus, food is a universal means of expressing sociability, and sharing food-related habits or preferences can foster a sense of belonging and identity. ${ }^{28}$ However, these behaviors and traditions are dynamic and, in a contemporary context, the act of eating should be viewed from a perspective of the transformation that food undergoes, one of the consequences of which is directly associated with the identity of food. ${ }^{29}$ Therefore, considering these transformations, contact with food crops from the garden can help create a different relationship with foods than the one that currently exists, with symbols and identity that differ from those of standardized food, whether it is ultra-processed or derived from highly industrialized agriculture.

The reports on changes in children's diets were notable, and created a connection with the foods grown by the children, encouraging them to try and consume them, increasing their repertoire of foods for consumption and leading to a more varied and healthy diet. Bernardon et al. ${ }^{15}$ found that the use of gardens as an instrument for promoting healthy eating habits was most evident when the objective of the project was to complement the meals served within the school, thereby becoming part of the children's daily diet. Similarly, Wansink et al. ${ }^{30}$ found that a statistically higher proportion of children chose vegetables from the school buffet when these had been grown in the school garden. Also, the study by Morgan et al. ${ }^{17}$ showed school gardens to be an effective strategy for increasing children's willingness to try F\&V. An intervention study in 8-11 year-olds from Los Angeles (USA) involving activities such as classes in a community garden, cooking activities and classes with nutrition-related content, reported an increased preference for vegetables and the perception that garden-grown foods tasted better than store-bought products. ${ }^{31}$ Ozer $^{10}$ noted that eating vegetables in the context of a school garden is a group activity which can reinforce the idea that consumption of these foods is a standard behavior.

In the present study, contact with soil and nature in childhood was deemed important by the interviewees. In a review study, Davis et al. ${ }^{5}$ noted that all of the studies they reviewed emphasized the experience of planting, tending and harvesting, and in some cases, preparing foods, as a key explanation for the effective results in improving diets because the children were actually involved in the whole process. A study on community gardens highlighted reports of gardeners' closeness with nature by "getting one's hands dirty" and through growing food crops, tasting the foods produced, and creating emotional connections with the garden. ${ }^{32}$ Coelho and Bógus ${ }^{33}$ pointed out that, through this contact, the garden allowed the people involved to experience and appreciate care. Health as care, self-care and sharing care can also be construed as reviving traditional practices of sociability and values, emerging as health practices aimed not only at individual returns but also producing new senses of identity and community. ${ }^{34}$

Greater appreciation of natural foods and awareness of the food system were also reported. Silva and Fonseca ${ }^{14}$ stressed the importance of teaching practices that consolidate human belonging to the natural world as a basis for other perceptions, because consumers are increasingly removed 
from the stages of food production and their environmental implications, rendering the context more difficulty to grasp. Currently, it is not only the children living in urban settings who are disconnected from the life cycle of foods, but often their parents as well. Besides having lost the skills to grow foods, they often have no cooking skills..$^{35}$ The results found in the present study on greater knowledge about foods corroborate findings reported in other studies, showing increased ability to identify vegetables and fruit, greater attention to the provenance of food and acquisition of knowledge on nutrition and gardening. ${ }^{12,16}$

In the present study, the interviewees noted that the experience of their child bringing home foods grown in the school garden and family involvement in preparing the foods grown in the school garden extended the impact on food to the rest of the family. These findings are consistent with data from previous studies. In a review study, Ozer ${ }^{10}$ stated that the goal of improving children's diets through the school garden appears to be better achieved when parents take part in the program, whether as volunteers, receiving educational materials developed for them, through homework that encourages parental participation or by promoting discussions within the family about food choices. The results of the study of Castro et al. ${ }^{36}$ showed that the children who participated in a community garden program had greater availability of fruit and vegetables at home and consumed larger amounts of fruit and vegetables. Regarding the relationship with gardens at home, the results showed that some children had gardens in their homes and shared seedlings and seeds with the school garden, whereas others set up gardens at home after getting involved in the school garden. Davis et al. ${ }^{16}$ also observed that, following a community garden intervention involving children, a greater number of families reported having a garden at home. Somerset et al. ${ }^{6}$ associated the school garden with greater motivation for parents to start domestic gardens.

The increase in school garden programs has not been accompanied by systematic assessment of the impact of these programs, with few scientific studies available in the related literature. ${ }^{10}$ The literature reports difficulties measuring the impact of school gardens using quantitative data. ${ }^{5,37}$ and there is a need for more studies with rigorous assessment designs and sufficiently large samples to test the effects of school garden programs. ${ }^{10}$ Nevertheless, this does not invalidate the outcomes and significant impact on the diet of participating children. The qualitative methodology was chosen for the present study to gain insights on the feelings and meanings of adequate and healthy food associated with the school garden activities, ${ }^{24}$ since these are determinants of dieting, although it does not have the objectivity of parameters typically taken into consideration when assessing the results of educational activities. ${ }^{38}$

The study results highlight the potential of an alternative education approach to the one traditionally employed in the field of food and nutrition. This is typically centered on dissemination of scientific knowledge with normative and behavioral discourse $\mathrm{e}^{18,39}$ and does not embrace food as a social construction incorporated into the network of culture-forming relationships. Santos ${ }^{18}$ pointed to the need for studies that encompass educational strategies and incorporate new 
assessment methods that are more suited to the teaching-learning process in the field of food and nutrition by including components that reflect the feelings and meanings of these actions. In Brazil, these issues have been addressed by public policies with the aim of tackling this scenario and promoting the health of the population. ${ }^{40-42}$ Thus, school gardens are incorporated in a context of redefining Food and Nutrition Security and Healthy and Adequate Food, an area where Brazil has gained international recognition. ${ }^{43,44}$ The development of gardens is consistent with the new Food Guide for the Brazilian Population, which includes the appreciation of social and cultural dimensions of dieting and food as found in nature as one of its principles, in addition to providing elements for educational practices to redefine the contemporary meaning of food, encouraging the production of foods in gardens and small spaces and appreciating cooking as a practice that resists the consumer society model. ${ }^{42,45}$

\section{Conclusion}

The results of the present study showed that school gardens can contribute to the promotion of adequate and healthy food. Contact with the cultivation of food crops provides knowledge and helps create a connection with food by sensitization to the act of eating. In practice, this leads to concrete changes in dietary practices, greater knowledge about foods and the food system, as well as to greater appreciation of the foods produced and motivation to try new foods. Therefore, school gardens represented a Food and Nutrition strategy based on involvement and direct contact with food or "nature", thus creating a meaningful connection between the children and food.

\section{Contributors}

Garcia MT and Coelho DEP worked in all steps, which consisted in study design; collection, analysis and interpretation of data, manuscript writing and proof-reading of final copy. Bógus CM participated in the study design, manuscript writing and proof-reading of final copy.

Conflict of Interest: The authors declare no conflict of interest.

\section{References}

1. Wang X, Ouyang Y, Liu J, Zhu M, Zhao G, Bao W, et al. Fruit and vegetable consumption and mortality from all causes, cardiovascular disease, and cancer: systematic review and dose-response meta-analysis of prospective cohort studies. BMJ 2014; 349:g4490.

2. Monteiro CA, Levy RB, Claro RM, Castro IRR, Cannon G. Increasing consumption of ultraprocessed foods and likely impact on human health: evidence from Brazil. Public Health Nutrition 2011; 14(01):5-13. 
3. Alves MN, Muniz LC, Vieira, MFA. Consumo alimentar entre crianças brasileiras de dois a cinco anos de idade: Pesquisa Nacional de Demografia e Saúde (PNDS), 2006. Ciênc Saúde Coletiva 2013; 18(11):3369-3377.

4. Bortolini GA, Gubert MB, Santos LMP. Consumo alimentar entre crianças brasileiras com idade de 6 a 59 meses. Cad Saúde Pública 2012; 28(9):1759-1771.

5. Davis JN, Spaniol MR, Somerset S. Sustenance and sustainability: maximizing the impact of school gardens on health outcomes. Public health nutrition 2015; 18(13):2358-2367.

6. Somerset S, Geissman R, Ball R, Flett M. School-based community gardens: Re-establishing healthy relationships with food. Journal of the Home Economics Institute of Australia 2005; 12:25-33.

7. Freitas MCS, Minayo MCS, Ramos LB, Fontes GV, Santos LA, Souza EC et al. Escola: lugar de estudar e de comer. Ciênc. Saúde Coletiva 2013; 18(4):979-985.

8. Boog MCF. Programa de educação nutricional em escola de ensino fundamental de zona rural. Rev. Nutr 2010; 23(6):1005-1017.

9. Burlandy L. Segurança alimentar e nutricional: intersetorialidade e as ações de nutrição. Saúde em Revista 2004; 6:9-15.

10. Ozer EJ. The effects of school gardens on students and schools: conceptualization and considerations for maximizing healthy development. Health Educ Behav. 2007; 34(6):846-863.

11. Ramos FP, Santos LAS, Reis ABC. Educação alimentar e nutricional em escolares: uma revisão de literatura. Cad Saúde Pública 2013; 29:2147-2161.

12. Somerset S, Markwell K. Impact of a school-based food garden on attitudes and identification skills regarding vegetables and fruit: a 12-month intervention trial. Public Health Nutrition 2009; 12(02):214-221.

13. Lautenschlager L, Smith C. Beliefs, knowledge, and values held by inner-city youth about gardening, nutrition, and cooking. Agriculture and Human Values 2007; 24(2):245-258.

14. Silva ECR, Fonseca AB. Hortas em escolas urbanas, Complexidade e transdisciplinaridade: contribuições para a educação ambiental e para a educação em saúde. Rev Bras Pesq Ed Ciências 2011; 11(3):35-53.

15. Bernardon R, Schmitz BDAS, Recine EGI, Rodrigues MDLCF, Gabriel CG. School Gardens in the Distrito Federal, Brazil. Revista de Nutrição 2014; 27(2):205-216.

16. Davis JN, Martinez LC, Spruijt-Metz D, Gatto NM. LA Sprouts: a 12-week gardening, nutrition, and cooking randomized control trial improves determinants of dietary behaviors. J Nutr Educ Behav. 2016; 48(1):2-11.

17. Morgan PJ, Warren JM, Lubans DR, Saunders KL, Quick GI, Collins CE. The impact of nutrition education with and without a school garden on knowledge, vegetable intake and preferences and quality of school life among primary-school students. Public Health Nutrition 2010; 13(11):1931-1940.

18. Santos LAS. O fazer educação alimentar e nutricional: algumas contribuições para reflexão. Ciênc. Saúde Coletiva 2012; 17(2):455-462. 
19. Sociedade Ecológica Amigos de Embu. Projeto Fonte Escola [Internet]. Embu das Artes, SP: SEAE. [acesso em: 24 out. 2016]. Disponível em: http://seaembu.org/seae/fonte-escola/

20. Franco MLPB. Análise de conteúdo. Brasília: Liber Livro; 2005.

21. Pinheiro ARO. A alimentação saudável e a promoção da saúde no contexto da segurança alimentar e nutricional. Saúde em Debate 2005; 29(70):125-139.

22. Brasil. Ministério do Desenvolvimento Social. Combate à Fome Conselho Nacional de Segurança Alimentar e Nutricional. Alimentação adequada e saudável. Relatório final. Brasília: CONSEA. GT; 2007.

23. Brasil. Ministério da Saúde. Política Nacional de Alimentação e Nutrição. Brasília: Ministério da Saúde; 2012.

24. Minayo MCDS, Deslandes SF, Cruz Neto O, Gomes R. Pesquisa social: teoria, método e criatividade. Petrópolis, RJ: Vozes; 2013.

25. Hersch D, Perdue L, Ambroz T, Boucher JL. The impact of cooking classes on food-related preferences, attitudes, and behaviors of school-aged children: a systematic review of the evidence, 2003-2014. Preventing Chronic Disease 2014; 11:E193.

26. van der Horst K, Ferrage A, Rytz A. Involving children in meal preparation: effects on food intake. Appetite 2014; 79:18-24.

27. Ahmed AT, Oshiro CE, Loharuka S, Novotny R. Perceptions of middle school educators in hawai 'i about school-based gardening and child health. Hawaii Medical Journal 2011; 70(7 Supl. 1):11.

28. Contreras J, Gracia M. Alimentação, sociedade e cultura. Rio de Janeiro: Editora Fiocruz; 2011.

29. Poulain JP. Sociologias da alimentação: os comedores e o espaço social alimentar. $2^{a}$ ed. Florianópolis: Editora UFSC; 2013.

30. Wansink B, Hanks AS, Just DR. A plant to plate pilot: a cold-climate high school garden increased vegetable selection but also waste. Acta Paediatrica 2015; 104(8):823-826.

31. Gatto NM, Ventura EE, Cook LT, Gyllenhammer LE, Davis JN. LA Sprouts: a garden-based nutrition intervention pilot program influences motivation and preferences for fruits and vegetables in latino youth. J Acad Nutr Diet. 2012; 112(6):913-920.

32. Hale J, Knapp C, Bardwell L, Buchenau M, Marshall J, Sancar F, Litt JS. Connecting food environments and health through the relational nature of aesthetics: gaining insight through the community gardening experience. Soc Sci Med. 2011; 72(11):1853-1863.

33. Coelho DEP, Bógus CM. Vivências de plantar e comer: a horta escolar como prática educativa, sob a perspectiva dos educadores. Saúde Soc. 2016; 25(3):761-770.

34. Luz MT. Novos saberes e práticas em saúde coletiva: estudo sobre racionalidades médicas e atividades corporais. $3^{\text {a }}$ ed. São Paulo: Hucitec; 2007.

35. Jackson E. Connecting people to the source of their food changing the way we think about food to improve health. N C Med J. 2015; 76(1):54-56.

36. Castro DC, Samuels M, Harman AE. Growing healthy kids: a community garden-based obesity prevention program. Am J Prev Med. 2013; 44(3):S193-S199. 
37. Christian MS, Evans CE, Nykjaer C, Hancock N, Cade JE. Evaluation of the impact of a school gardening intervention on children's fruit and vegetable intake: a randomised controlled trial. Int J Behav Nutr Phys Act. 2014; 11:99.

38. Diez Garcia RW, Medeiros MATd, Domene SMÁ. Revista de Nutrição: espaço de interlocução interdisciplinar da área de alimentação e nutrição. Rev Nutr. 2010; 23(1):5-6.

39. Castro IRR, Souza TSN, Maldonado LA, Caniné ES, Rotenberg S, Gugelmin SA. A culinária na promoção da alimentação saudável: delineamento e experimentação de método educativo dirigido a adolescentes e a profissionais das redes de saúde e de educação. Rev. Nutr. 2007; 20(6):571-588.

40. Brasil. Ministério do Desenvolvimento Social e Combate à Fome. Marco de referência de educação alimentar e nutricional para as políticas públicas. Brasília: Ministério do Desenvolvimento Social e Combate à Fome; 2012.

41. Brasil. Ministério do Desenvolvimento Social. Câmara Interministerial de Segurança Alimentar e Nutricional. Estratégia Intersetorial de prevenção e controle da obesidade: recomendações para estados e municípios. Brasília: CAISAN; 2012.

42. Brasil. Ministério da Saúde. Guia alimentar para a população brasileira. Brasília: Ministério da Saúde; 2014.

43. Monteiro CA, Cannon G, Moubarac JC, Martins APB, Martins CA, Garzillo J, et al. Dietary guidelines to nourish humanity and the planet in the twenty-first century. A blueprint from Brazil. Public Health Nutr. 2015; 18(13):2311-2322.

44. Organização das Nações Unidas para Agricultura e Alimentação. O estado da segurança alimentar e nutricional no Brasil: um retrato multidimensional. Brasília: FAO; 2014. 90 p.

45. Castro IRR. Challenges and perspectives for the promotion of adequate and healthy food in Brasil. Cad Saúde Pública 2015; 31(1):07-09.

Received: November 20, 2016

Reviewed: January 16, 2017

Accepted: February 15, 2017 